engineers, Gabinete do Plano do Zambezi (GPZ) in Tete revealed that they intended to fill the lake to capacity during a period of four months, allowing less than 60 cubic metres of water to discharge daily to the gorge below the dam. In normal years, the average flow through the gorge is of the order of 2,000-3,000 cubic metres per second.

Recommendations made by the team to the GPZ and the then Portuguese and Mocambique governments included allowance of a minimum discharge from the dam during the filling phase of 400-500 cubic metres per second with the lake taking between one to two years to reach maximum capacity, thus reducing the expected detrimental effects associated with prolonged water reduction in the Lower Zambezi. The gorge below the dam, approximately $25 \mathrm{~km}$ long (river depth between 30 $40 \mathrm{~m}$ ), has no source of water other than the dam. Four major rivers enter the Zambezi between the gorge and the coast, $560 \mathrm{~km}$ downstream, namely the Luia, Revuboé, Mazoe (Luenha) and Shire, the Shire draining Lake Malawi to the north. Unpublished data supplied by the GPZ shows that these rivers add little by way of volume (though the Shire considerably alters the chemistry of the Zambezi below their confluence) and then only during the latter part of the wet season (mid-January to late March).

Accompanying a press announcement of closure (Noticias de Mocambique, 28.11.74) was the comment that the dam would be completely closed until such time as the water level reached $306.2 \mathrm{~m}$ AMSL (approximately three weeks after closure according to the report), after which time water would be discharged into the gorge. The lake would then fill at a slower rate. The minimum discharge recommendations were ignored. The engineers anticipated that little or nu noticeable difference in river level would occur during this early filling phase due to the expected onset of the rains. This statement contradicts the river flow data supplied by the GPZ and gives no consideration to the possible long-term ecological consequences of such action. To compound the problem, local rains did not begin until two to three weeks after closure. Within seven days of closure, the river at Tete (approximately $120 \mathrm{~km}$ downstream from Cabora Bassa) was reported to have dropped to dry season levels. By February 8 this year, levels had dropped sufficiently to prevent operation of water supply intakes for Tete, and no discharge from the dam had taken place up to this date. At the same time, large numbers of spawning fish were stranded in the lower river and slaughtered in large numbers by local Africans.

This apparent disregard of recom- mendations made with long-term considerations in mind bodes ill for future co-operation between ecologist and engineer and could have important long-term repercussions for the agriculture (mainly sugar cane), fisheries and game reserves of the Lower Zambezi Valley and its floodplains. Important decisions, such as the timing of artificial floods and the controlled fluctuation of water level in order to facilitate development of hydrophytes, essential for fisheries development in the new lake, must be taken in the near future. A dialogue between ecologist and engineer is essential if a balanced use of the resource is to be made.

Bryan R. Davies

Institute for Freshwater Studies,

Rhodes University, Grahamstown.

Cape Province, South Africa

\section{African finds}

SIR,-In his article on the Leakeys' work at East Rudolf (Nature, February $20,1975)$ Bernard Wood writes, of the Taung discovery in 1924: "It was fortunate that the remains of a fossil monkey had been recognised at the same quarry only a few months previously." In fact, fossil baboons were found at Taung as early as 1920 . On 19th May 1920 , a paper on seven or eight fossil baboons from Taung was read in Cape Town before the Royal Society of South Africa by S. H. Haughton, subsequently Director of the Geological Survey of the Union of South Africa, and still later, Honorary Director of the Bernard Price Institute for Palaeontological Research at the University of the Witwatersrand. Haughton's paper of 1920 was not published in full, though he made his notes available to $R$. A. Dart, R. Broom and J. H. S. Gear. An abstract of Haughton's communication was published in 1925. To accommodate the small baboon skulls from Taung, he had proposed to create a new species, Papio antiquus. However, as his paper was not published and as no type was designated, the name $P$. antiquus was both a nomen dubium and a nomen non rite publicatum. Gear recognised that the sample of cercopithecoids from Taung included two different species to which he gave the names, $P$. africanus and $P$. izodi.

Presumably, the "fossil monkey" referred to by Wood was a baboon cranium which, in 1924, one of Dart's students, Josephine Salmons, recovered from the home of E. G. Izod, a director of the Northern Lime Company. This find led Dart to request R. B. Young, then professor of geology at the Witwatersrand University and about to survey the Taung area, to speak to the Timeworks manager in the hope of obtaining more specimens.
The recovery of the Taung australopithecine skull, said by Wood to have been discovered by accident, actually occurred as follows: $\mathrm{Mr}$ M. de Bruyn, a miner at Taung, had been interested for many years in collecting fossilized bones. A week before Professor Young's visit, in October 1924, de Bruyn had blasted out a number of fossils. These included the brain cast of a baboon and, embedded in another fragment of breccia, a second, larger endocast; among the other rock fragments part of a lower jaw was exposed. The manager, A. E. Spiers, and de Bruyn showed the collection to Young, who selected certain pieces which Spiers railed to Dart. It was the second, larger endocast which turned out to be that of Australopithecus. Another piece of rock made a perfect join with the former and from it Dart extracted the face. (There is no evidence whatever to support Bernard Wood's statement that "The child's skull was in fact identified ... by Professor Young": indeed this would have been virtually impossible since most of the skull was totally embedded in the matrix. Only a part of the endocast was showing on the surface of one piece and the back of the lower jaw on another piece. Identification was out of the question until Dart had extracted the specimen from its matrix in time for Christmas, 1924.)

The article also stated that Taung was situated "in what was then Bechuanaland". This common mistake arose because Taung was situated in the northernmosit part of the Cape Province, an area formerly known as 'British Bechuanaland' (and totally distinct from 'Bechuanaland'). But this are was in 1924 an integral part of the Union of South Africa, entirely separate from the Bechuanaland Protectorate which is today the Republic of Botswana. This old name of the northern Cape Province led several scientists and textbook writers erroneously to place Taung in 'Bechuanaland' or even 'Botswana'.

Wood's statement that ' $\ldots$ work has been resumed recently at three of these sites' (in the Transvaal) is misleading, since Brain resumed excavation at Swartkrans in 1965, while Tobias and Hughes began excavating at Sterkfontein in 1966 . Work has continued ever since, in the case of Sterkfontein without any interruption for 48 weeks a year for over eight years. Hence, although the article admirably reflects recent work in East Africa, it does scant justice to the palaeo-anthropological researches in the Transvaal over the past decade.

Phillip V. Tobias

Department of Anatomy,

University of the Witwatersrand,

Johannesburg 2001, South Africa 